\title{
A Preliminary Typology for Beads from the Neolithic and Chalcolithic Levels of Barcın Höyük
}

\section{Emma Baysal}

\section{Q OpenEdition \\ 1 Journals}

\section{Electronic version}

URL: http://journals.openedition.org/anatoliaantiqua/280

DOI: 10.4000/anatoliaantiqua.280

\section{Publisher}

IFEA

\section{Printed version}

Date of publication: 1 January 2014

Number of pages: 1-10

ISBN: 9782362450136

ISSN: 1018-1946

\section{Electronic reference}

Emma Baysal, « A Preliminary Typology for Beads from the Neolithic and Chalcolithic Levels of Barcın Höyük », Anatolia Antiqua [Online], XXII | 2014, Online since 30 June 2018, connection on 18 December 2020. URL : http://journals.openedition.org/anatoliaantiqua/280 ; DOI : https://doi.org/10.4000/ anatoliaantiqua. 280 


\section{ANATOLIA ANTIQUA ESKI ANADOLU}

\section{XXII}

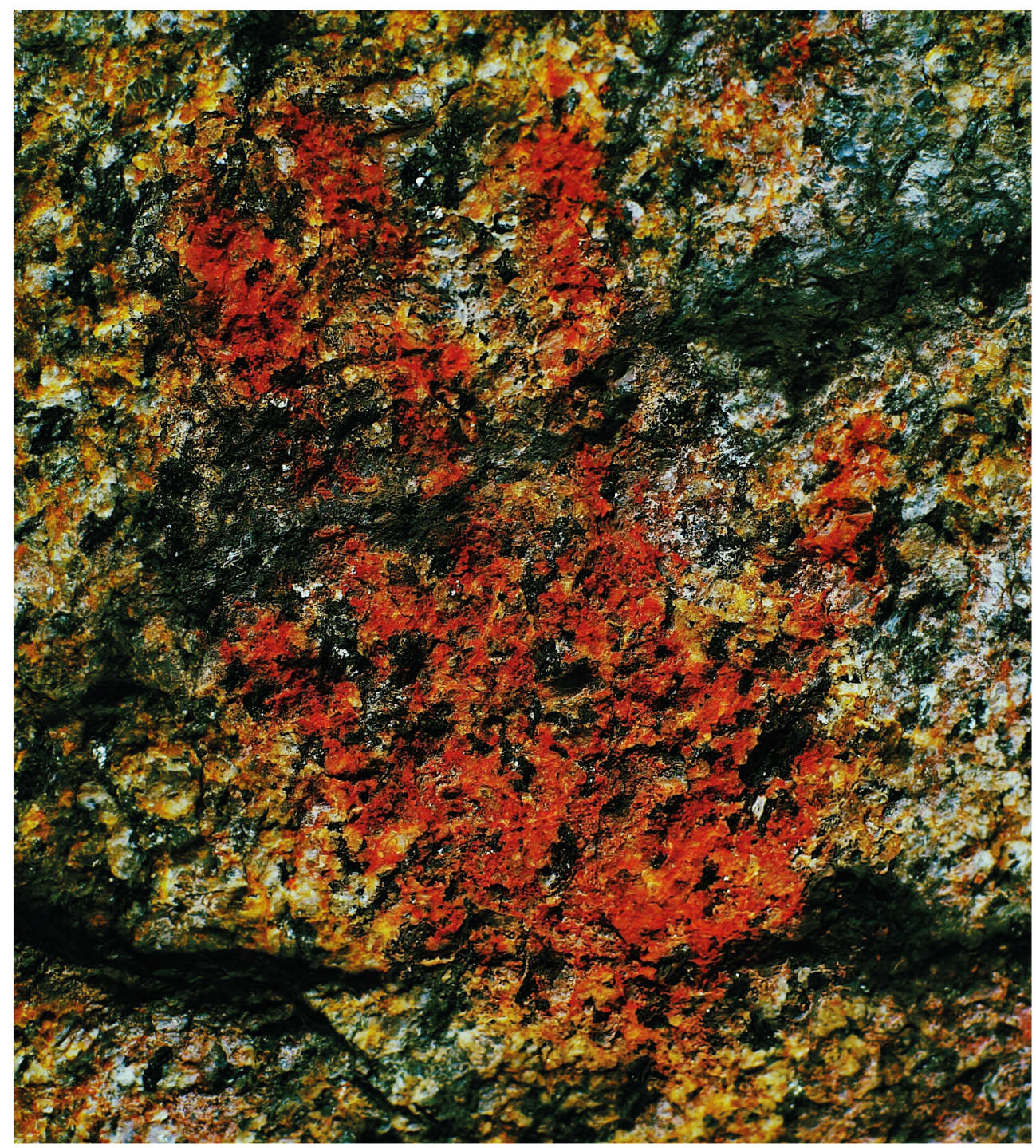

INSTITUT FRANÇAIS D'ETUDES ANATOLIENNES GEORGES-DUMEZIL CNRS USR 3131

DE BOCCARD 


\section{TABLE DES MATIERES}

Emma BAYSAL,

A preliminary typology for beads from the Neolithic and Chalcolithic levels of Barcın Höyük

William ANDERSON, Jessie BIRKETT-REES, Michelle NEGUS CLEARY,

Damjan KRSMANOVIC et Nikoloz TSKVITINIDZE,

Archaeological survey in the South Caucasus (Samtskhe-Javakheti, Georgia):

Approaches, methods and first results

Eda GÜNGÖR ALPER,

Hellenistic and Roman period ceramic finds from the Balatlar Church excavations in

Sinop between 2010-2012

Ergün LAFLI et Gülseren KAN ŞAHİN,

Hellenistic ceramics from Southwestern Paphlagonia

Oğuz TEKIN,

Weights of Lysimachea from the Tekirdağ Museum and various collections

Oğuz TEKIN,

Three weights of Lampsacus

Julie DALAISON et Fabrice DELRIEUX,

La cité de Néapolis-Néoclaudiopolis : histoire et pratiques monétaires

Martine ASSENAT et Antoine PEREZ,

Amida 4. Constance II et Amida

Sencan ALTINOLUK et Nilüfer ATAKAN,

Abrasax: A magical gem in the Istanbul Archaeological Museums

Bahadır DUMAN,

A group of local production Middle Byzantine period pottery from Tripolis:

'Micaceous White Painted Ware'

CHRONIQUES DES TRAVAUX ARCHEOLOGIQUES EN TURQUIE, 2014

Jean-Charles MORETTI,

avec la collaboration de Nicolas BRESCH, Isabel BONORA, Jean-Jacques MALMARY et

Olivier RISS,

Claros, le Temple d'Apollon : travaux réalisés en 2013

Suat ATEŞLIER,

On the excavations of the Zeus Temple of Alabanda 
Olivier HENRY,

avec Ayşe Güliz BİLGIN ALTINÖZ, Jesper BLID, Ömür Dünya ÇAKMAKLI, Andrew DUFTON, Agneta FRECCERO, Linda GOSNER, Ragnar HEDLUND, Pascal LEBOUTEILLER,

Vasilica LUNGU, Felipe ROJAS, Fredrik TOBIN, Baptiste VERGNAUD et

Andrew WATERS,

La mission Labraunda 2013 - Rapport préliminaire

Dominique BEYER, Isabelle CHALIER, Françoise KIRNER,

Françoise LAROCHE-TRAUNECKER et Aksel TIBBET,

Zeyve Höyük - Porsuk. Rapport préliminaire sur la campagne 2013

Çiğdem MANER,

Preliminary report on the first season of the Konya-Ereğli (KEYAR) survey 2013 


\section{A PRELIMINARY TYPOLOGY FOR BEADS FROM THE NEOLITHIC AND CHALCOLITHIC LEVELS OF BARCIN HÖYÜK}

\section{INTRODUCTION}

Beads have received little attention as part of the material culture repertoire of Anatolian prehistory. As the artefact in closest contact with prehistoric communities, worn around the body or on clothes, they are key to understanding the way that prehistoric people viewed themselves and constructed their identities. Although the Neolithic in Turkey volumes (for example Caneva 2007; Cauvin et al. 2007; Erim-Özdoğan 2011; Esin and Harmankaya 2007; Karul 2007; Öztan 2007) have hinted at the richness of Anatolian bead assemblages, there is still a paucity of detailed publication. The assemblage of beads from Barcin Höyük currently consists of around 600 items of a variety of forms and materials, the majority of which date to the Neolithic period. This article proposes a typology for this assemblage.

Barcın Höyük is located in Bursa province (Fig. 1) and has been excavated as part of a longterm project looking at the early farming communities of the Marmara region (Gerritsen et al. 2013a and b). The site consists of two mounds, eastern and western and it is the Chalcolithic and Neolithic phases of the former, larger, mound that concern us here. Five main Neolithic phases have been identified at the site, VIa (latest) to VIe (earliest) on the basis of stratigraphy and pottery assemblages (Gerritsen et al. 2013a: 95). Absolute dates give a Neolithic occupation range from $6600-6500 \mathrm{cal}$. B.C. to 6000 cal. B.C. (Gerritsen et al. 2013a: 97). The site gives important information about the neolithization process in northwestern Anatolia and allows further understanding of the region's relationship to both Central Anatolia and the Aegean and Balkan areas. To date evidence suggests that there are some significant changes in material cultural traditions in the earlier Neolithic levels of occupation of the site. As part of this material culture repertoire beads may give clues to the way that materials were used and valued. The bead assemblage hints at material and technological links to both wider traditions of the Anatolian and Near Eastern Neolithic and to practices which relate more strongly to the Aegean and Balkan areas.

This article uses the artefacts recovered between 2007 and 2013 to propose individual typologies for the beads of stone, shell, clay and bone and looks at the relationship between form and material. In so doing it asks how value may have been ascribed to the beads and the motivation for their production. Discussion of the contextual definition of the beads, and variation in their deposition through time will be included in a future article. Only three beads have been recovered from Chalcolithic levels at the site and these have been included here, although their forms suggest that they may be residual from the Neolithic phases (Özbal et al. forthcoming). The assemblage has a large component of blue coloured beads of a variety of forms and materials. These are discussed separately as their colour rather than their material is deemed to be the most important element.

\section{BEAD MATERIALS AND TYPOLOGY}

In the creation of bead typologies there has been a proliferation of terminology, often created with specific assemblages in mind and often with significant redundancy when used in comparative works. For the purpose of creating an understandable, and useable, typology here a combination of Beck's (1928) early and comprehensive typology with careful description and illustration is used. This is intended to render the material comparable to other assemblages, an aspect of bead research that is in urgent need of further work.

This typology has been arrived at using the analysis of raw material and metric data to classify beads according to shape, size and proportions. This technique was pioneered by Horace Beck in the

\footnotetext{
*) British Institute of Archaeology at Ankara, Tahran Caddesi 24, 06700 Kavaklıdere, Ankara, Turkey. emmabaysal@gmail.com
} 


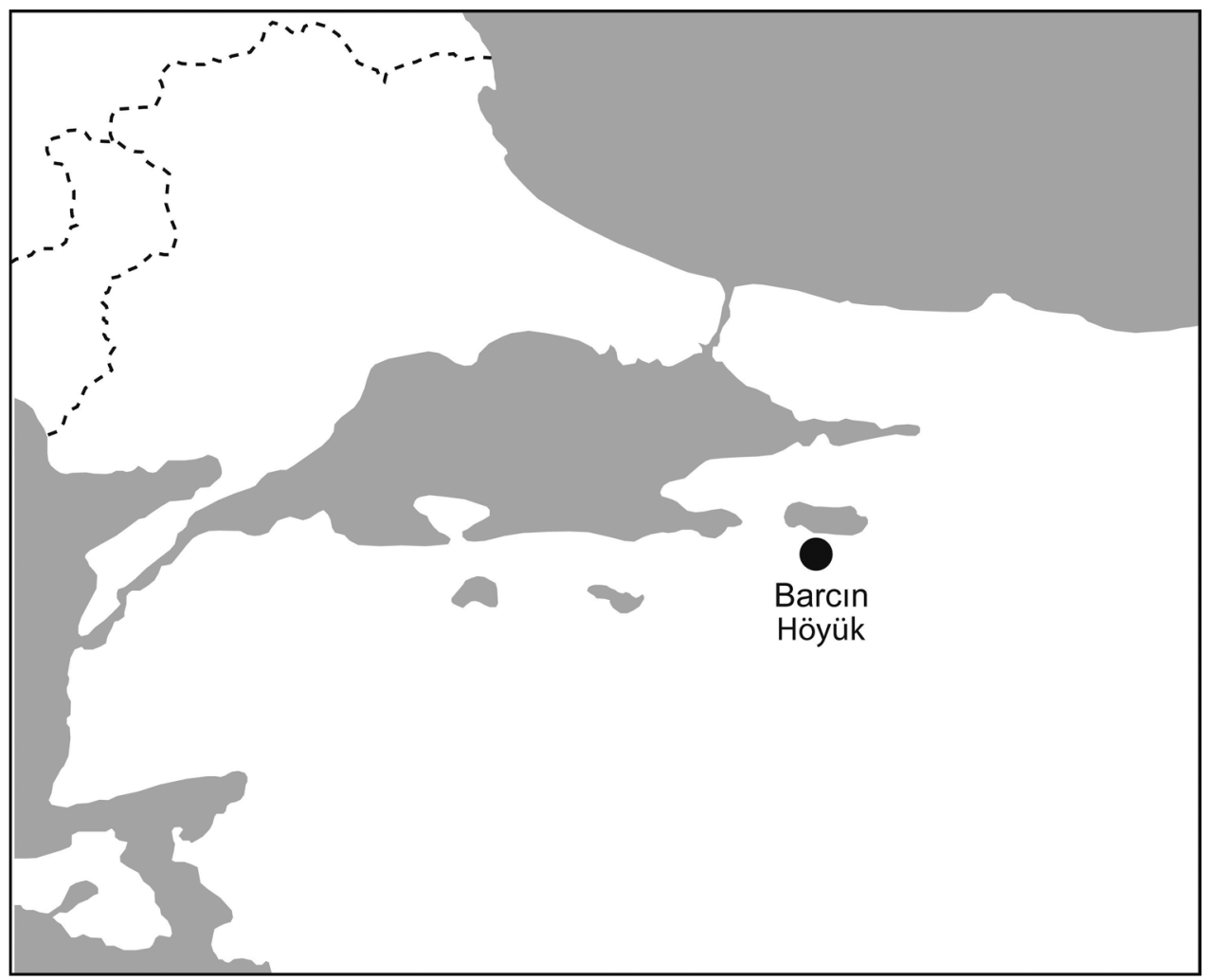

Fig. 1 : Location of Barcın Höyük.

1920 s and it is to his original 'master' typology (Beck 1928) that reference is made in categorizing the beads of Barcın Höyük. Where Beck's typology does not provide a suitable classification, a descriptive name for a form along with a description of its salient features has been included. All materials are included, on the basis that perceptions of material during prehistory are not well understood and there are examples in this assemblage of the imitation of one material in another, indicating that appearance was probably more significant than composition.

Weight is not considered as part of the typology as in all cases the amounts of raw material required are so small that their weight would have had no significance to anyone engaged in raw material procurement. The entire assemblage so far recovered from the site could be fitted into a small bag. It is the very portability of beads that lends them much of their appeal as an object of study. The freedom with which they could have moved through the landscape, from one person and one community to another makes them an intriguing subject. Indeed there is unequivocal evidence for their long distance movement in Anatolia from the Epipalaeolithic onwards (Baysal 2013b) and as such their involvement in interactions and trade should be considered.
Of the total of 567 beads that are considered in this article, $24 \%$ are stone, $31 \%$ shell of marine and freshwater origin, $2 \%$ are bone, $2 \%$ clay; the largest proportion $(41 \%)$ are turquoise blue in colour and made of a combination of stone and manufactured materials. Each of these types is considered separately in the following sections with discussion of form, size, variation and overlap of form between material types.

\section{Stone beads and pendants}

The stone bead typology is relatively limited with only seven common bead forms (Fig. 2) and one recurrent pendant type; there are a number of other pendants and beads of which only single examples have been found and they are therefore regarded as 'one-offs' (Table 1; 3 ). The vast majority of the stone beads are simple short forms, basic disc beads predominate, comprising $72 \%$ of the assemblage, and are further augmented by variations on this basic form, 'washers' and 'large discs' (see Table 1) which are a further $7 \%$. This pattern of intensive use of disc beads is common to all reported Neolithic assemblages from Anatolia and the Near East (for example Bar-Yosef Mayer 2013; Caneva 
2007; Cauvin et al. 2007; Erim-Özdoğan 2011; Esin and Harmankaya 2007; Hamilton 2005; Baysal 2013a, forthcoming a and b; Wright and Bains 2007; Wright et al. 2008; Wright and Garrard 2003).

Longer stone beads are less common, piercings rarely exceed $4 \mathrm{~mm}$, the majority is less than $2 \mathrm{~mm}$ in length. There are a small number of beads with piercings around $10 \mathrm{~mm}$, in cylinder, sub-spherical or globular form. Longer piercings tend to have a larger diameter, those of $4 \mathrm{~mm}$ or more have average piercing sizes of more than $2.5 \mathrm{~mm}$, greater than the assemblage's average. The preference for shorter beads indicates that long piercings may have been both more time consuming and more difficult to achieve. The assemblage of blue beads, discussed below, shows an interesting contrast with the general stone bead typology in this respect.

The minor technological variations in stone bead production consist of piercing direction and finishing, the profile of the outer surface of the bead and the degree of polish of all surfaces. Piercing types can vary within a single form, this is particularly obvious in those with shorter piercings, which typically might have been pierced from one side, from both sides, or might have the piercing smoothed to leave no trace of piercing methodology (Beck perforation types I, II, III and IV respectively). Straight sided piercings are by far the most common $(70 \%)$, hourglass are relatively common $(27 \%)$ and the remainder are either one sided (1\%) or of indistinct form $(2 \%)$. This variation is typical of the majority of disc, washer and large disc beads, which also show little consistency in their finer details of form and finish. A good example of this variation is in the outer profile of the bead edges, which range from completely straight to considerably curved (51\% straight, $49 \%$ with some degree of curvature); this may indicate different finishing methods, possibly individual abrasion as opposed to group abrasion. There are some indications that manufacturing style was related to raw material, examples such as the orange 'globular' beads (Fig. 2: 1) and the white marble disc beads (Fig. 2 and 3) both show consistency in their final appearance.

Raw materials for the smallest beads seem to have been primarily chosen for two reasons, ease of working and colour. The stone types used are mostly less than four on the Mohs scale, of metamorphic and sedimentary origin, and would have presented little trouble in drilling and shaping. Limestone and marble of various colours dominate in the manufacture of all bead shapes in the stone assemblage (approximately three quarters of the assemblage). The square pendants (Table 1) are made from schist, another easy to work stone. Although most stone procurement was probably on a local basis and related to locally available materials, an exception is seen in the assemblage of blue coloured beads that forms slightly more than $40 \%$ of the total assemblage and is discussed in detail below.

Colour had an important role to play in the choice of materials at this site. For the purposes of this study colour is defined in broad terms (see Table 2), the natural colour variation in materials probably restricted the precision of colour choice for the manufacturers. An overview of the stone beads makes clear the repeated choice of certain coloured materials in the production of certain bead forms (Table 2; for example Fig. 2: 1, orange globular beads). At this stage it is clear that there is a positive correlation between colour and form in some bead types. The ubiquitous disc bead is an exception and is manufactured from the widest range of colours, and indeed the widest range of materials. However, these are not necessarily the most striking of colours, including many shades of beige and grey.

White marble disc beads are relatively numerous, with 18 examples ( $13 \%$ of the stone bead assemblage) with an average diameter of $10 \mathrm{~mm}$ these are considerably larger than the average stone disc bead.

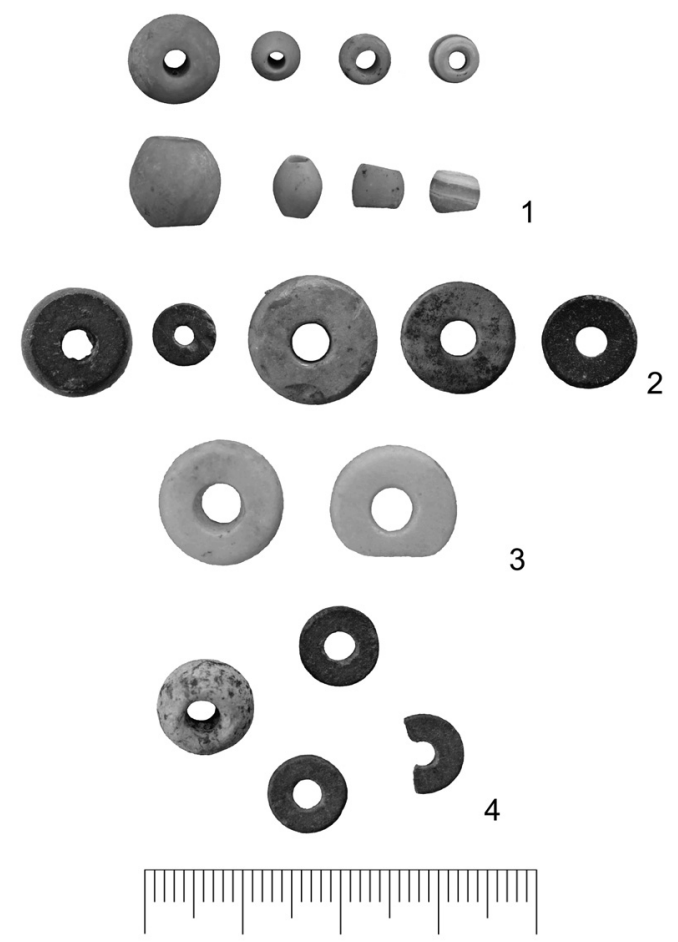

Fig. 2 : A variety of stone beads from Barcın Höyük. 1: orange 'globular', 2: typical disc beads, 3: White marble disc beads, 4: Group of disc beads. 
Table 1 : Stone bead and pendant types found at Barcin Höyük (illustrated in Fig. 3).

\begin{tabular}{|l|l|l|}
\hline \multicolumn{1}{|c|}{$\begin{array}{l}\text { Bead/ } \\
\text { pendant form }\end{array}$} & \multicolumn{1}{|c|}{$\begin{array}{c}\text { Beck } \\
\text { equivalent }\end{array}$} & \multicolumn{1}{c|}{ Description } \\
\hline Disc & $\begin{array}{l}\text { A.1.b, A.2.b } \\
\text { Perforation I, } \\
\text { II, III, IV or V V }\end{array}$ & $\begin{array}{l}\text { Length less than 1/3 of diameter, } \\
\text { either straight or slightly curved } \\
\text { sides. Piercing types may vary. }\end{array}$ \\
\hline Washer & $\begin{array}{l}\text { Similar to A.2.b } \\
\text { Perforation I, II, } \\
\text { III, IV }\end{array}$ & $\begin{array}{l}\text { Length less than 1/5 of diameter. } \\
\text { Piercing types may vary. }\end{array}$ \\
\hline Large disc & $\begin{array}{l}\text { A.2.b, B.2.b } \\
\text { Perforation I, II, } \\
\text { III, IV or V }\end{array}$ & $\begin{array}{l}\text { Diameter is more than 10mm, pro- } \\
\text { portions vary from 1/3 to 9/10 of } \\
\text { diameter. Piercing types may vary. }\end{array}$ \\
\hline Sub-spherical & $\begin{array}{l}\text { I.D1.a } \\
\text { Perforation II, } \\
\text { IV or V }\end{array}$ & $\begin{array}{l}\text { This type has no flattening at the } \\
\text { end around piercing. Piercing al- } \\
\text { ways from both ends. }\end{array}$ \\
\hline Globular & $\begin{array}{l}\text { I.C.1.b } \\
\text { Perforation II, } \\
\text { IV or V }\end{array}$ & $\begin{array}{l}\text { Flattened at ends around piercing, } \\
\text { sides more curved than Beck's ex- } \\
\text { ample. Piercing always from both } \\
\text { ends. }\end{array}$ \\
\hline Cylinder & $\begin{array}{l}\text { I.D.2.b } \\
\text { Perforation II, } \\
\text { IV or V }\end{array}$ & $\begin{array}{l}\text { Length is more than 1 1/10 of di- } \\
\text { ameter. Sides are straight. Piercing } \\
\text { is always from both ends. }\end{array}$ \\
\hline Ring & $\begin{array}{l}\text { I.A.1.a, I.B.1.b } \\
\text { Perforation VI } \\
\text { a or b }\end{array}$ & $\begin{array}{l}\text { Piercing more than 1/3 of diameter. } \\
\text { Outer surface curved. }\end{array}$ \\
\hline $\begin{array}{l}\text { Square } \\
\text { pendant }\end{array}$ & $\begin{array}{l}\text { Perforation I } \\
\text { Miscellaneous }\end{array}$ & $\begin{array}{l}\text { Perforation close to one corner, } \\
\text { thin flat profile with rounded edges. }\end{array}$ \\
\hline $\begin{array}{l}\text { A number of one-off pendants and } \\
\text { beads, various forms and numbers } \\
\text { of piercings. }\end{array}$ \\
\hline
\end{tabular}

They also have remarkably consistent dimensions, an average thickness of more than $3 \mathrm{~mm}$ and piercing also averaging $3 \mathrm{~mm}$. The finish of the piercing, hourglass in form, and the beads' surface with slightly rounded edges all indicate a degree of standardization in manufacture. These are significant both in terms of the colour choice but also in their possible relationship to wider practices of the Neolithic period also involving shell beads and are discussed in more detail below.

The one-off beads and pendants include a range of forms and materials; expedient production is seen in three pierced river-rolled pebbles, all of white marble. There are two long biconical meerschaum beads, the material for which must have originated in the Eskişehir region. A single example of a bellshape with flattened ends is more reminiscent of one of the blue bead forms than the rest of the stone assemblage.

There is some degree of correlation between the stone bead types identified at Barcin and those described by Bar-Yosef Mayer (2013) in her typology for the southern Levant. In general terms the stone beads of Barcin are seen to conform to the widest of

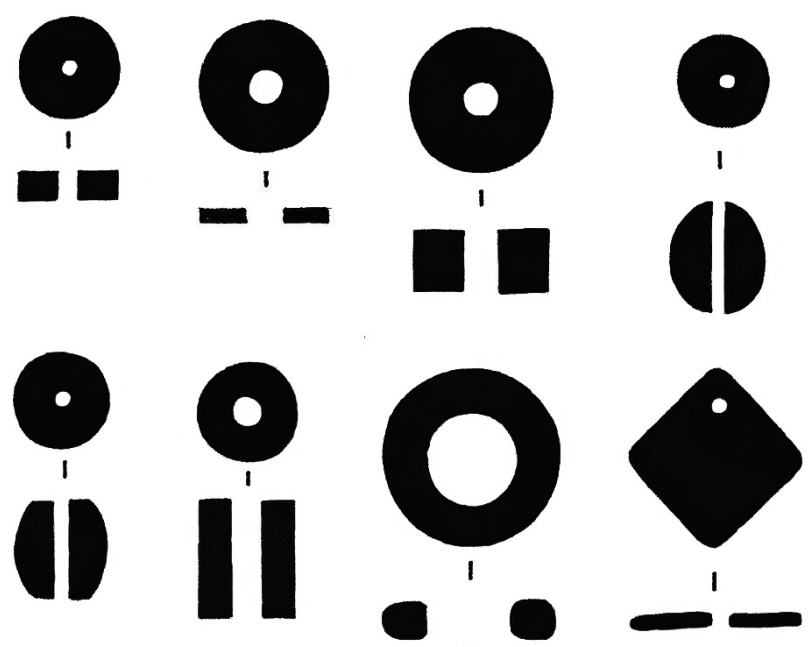

Fig. 3 : Schematized diagram of the stone bead types at Barcın Höyük.

Table 2 : Correlation between colour and form in stone beads at Barcın Höyük, see Table 1 for details of forms.

\begin{tabular}{|l|l|c|}
\hline \multicolumn{1}{|c|}{ Colour } & \multicolumn{1}{c|}{ Bead type } & Percentage \\
\hline Orange/yellow & $\begin{array}{l}\text { Mostly globular/sub- } \\
\text { spherical, a few discs and } \\
\text { large discs }\end{array}$ & 11 \\
\hline White/cream/beige & $\begin{array}{l}\text { Mostly discs and a few as- } \\
\text { sorted others } \\
\text { Mostly discs, also square } \\
\text { Black/grey }\end{array}$ & 37 \\
$\begin{array}{l}\text { Red } \\
\text { Green }\end{array}$ & $\begin{array}{l}\text { Mostly discs, a few others } \\
\text { Discs and 1 washer }\end{array}$ & 8 \\
\hline
\end{tabular}

prehistoric traditions, although raw material procurement practices are probably related to local sources. This remains to be established by locating the sources and testing their chemical signatures.

\section{Blue beads (various materials)}

In addition to the standard stone beads at Barcin the site also has a large component of blue coloured beads (more than $40 \%$ ). These are made of a combination of stone $(64 \%)$ and what are currently assumed to be imitations of the stone examples made in a clay or clay-like material with coloured surface treatment (36\%). The stone material has provisionally been identified as odontolite, known to have been used as a substitute for turquoise stone because of its vibrant colour. 'Odontolite' is the result of an ancient thermal treatment of fossil ivory above $550^{\circ} \mathrm{C}$ under oxidising conditions (Reiche et al. 2000: 634) according to analyses of artefacts from the National Museum of Natural History in Paris. 
The analytical work of Reiche et al. (2000: 636) has disproved the widely held belief that the blue colour derives from vivianite or copper while also distinguishing between green examples of fossil bone which are identified as hydroxylapatite and the blue fossil ivory items which are fluorapatite. There are provisionally thought to be some examples of the former at Barcin, but the majority of the blue stone items are currently considered to be fluorapatite. Analyses of the Barcin examples are currently under way to establish the exact composition and technology of the latter (Baysal et al., in preparation).

The beads produced from these materials are various shades of turquoise in colour and have polished surfaces. This material is harder than most of the stone used at the site (Mohs 5), and would therefore have required more effort to work. Owing to the lack of disc beads in the blue assemblage the average length is longer than in the stone assemblage (approx. $8 \mathrm{~mm}$ ) and the piercing diameter is smaller at an average of less than $1.4 \mathrm{~mm}$. Technically, piercing these beads was quite challenging, broken examples show the difficulty that was encountered in getting the bi-directional piercing to meet in the middle of the bead.

The material was worked into a variety of forms (Table 3) the most common being short flat shapes (more than 20\%). Blue disc beads are relatively rare (less than 10\%) suggesting that the blue beads were distinguished from other stone beads. It is not yet clear whether this related to the place of manufacture, there is as yet no evidence that blue stone beads were made at Barcin. The forms of the blue beads overlap to some extent with the main stone bead typology, however, it includes a variety of forms that are unique to blue coloured beads, regardless of material. These are the chip, long bead with round section, long with lenticular section, very long with lenticular section, short with wide lenticular section and bell-shape with wide lenticular section (Table 3). All these forms except the 'chip' are also found reproduced artificially along with the double sphere, which has not yet been found in stone. Notably the shapes that are associated with blue colouring are almost all flattened lenticular forms, a profile that is not seen in either stone or shell beads.

The apparent skeuomorphism within the blue bead assemblage indicates that the blue colour took precedence over material. In a similar example from the site of Tell el-Kerkh (Taniguchi et al. 2002) it has been suggested that there was a conscious effort to imitate turquoise, which is difficult to procure, having a very limited number of sources, the closest to Anatolia being Iran and Sinai. The imitation of turquoise is seen as being the motivation for the development of faience technology in later periods. At Tell el-Kerkh manufactured blue beads are found juxtaposed with genuine turquoise, in a context that indicates that specialized craft production was being practiced (Taniguchi et al. 2002: 176). The dating of the Neolithic site is broadly comparable to Barcin Höyük (ranging from 6500-5000 uncal. B.C.) however the number of these beads found at el-Kerkh is very small. The form of the beads is similar to the majority of the blue beads at Barcin and is also said to be a common form in the main stone bead assemblage at el-Kerkh. This latter observation indicates that while the el-Kerkh blue beads were congruent with wider bead production and use at the site, those at Barcin largely have a form that belongs only to the blue bead corpus. Could this mean that the form and technology were derived from elsewhere? Current evidence suggests that their form is not native to Barcin, hopefully further studies will elucidate the details.

The marked preference for the colour blue raises the question of whether the use and manufacture of blue materials was intended to imitate turquoise and that this colour was imbued with a symbolic value. The preference for this specific blue shade is supported by the apparent artificial manufacture of beads of a very similar colour. Blue beads are also reported from Köşk Höyük (Öztan 2010) although their composition is not defined; this may indicate a more widespread preference for blue beads. There is also a possibility that the preference for blue is distantly related to an earlier preference for green beads that is known to have existed in the Levant (Bar-Yosef Mayer and Porat 2008). The early preference for green is suggested to have been related to incipient agriculture and beliefs relating to fertility (Bar-Yosef Mayer and Porat 2008).
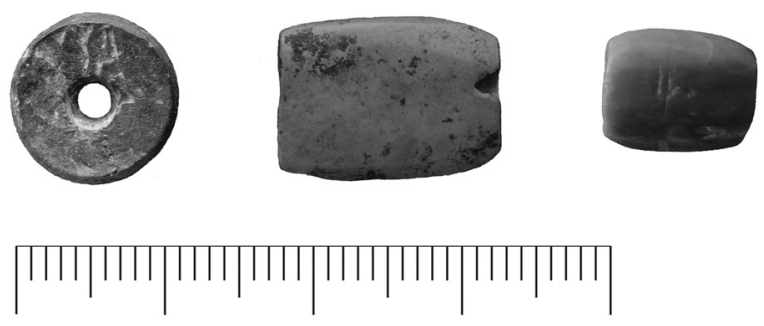

\footnotetext{
Fig. 4 : Examples of blue beads from Barcın Höyük: large disc bead, short with wide lenticular section.
} 
Table 3 : Blue bead types found at Barcın Höyük (illustrated in Fig. 5).

\begin{tabular}{|c|c|c|}
\hline $\begin{array}{l}\text { Bead/pendant } \\
\text { form }\end{array}$ & $\begin{array}{c}\text { Beck } \\
\text { equivalent }\end{array}$ & Description \\
\hline Disc & $\begin{array}{l}\text { A.1.b, A.2.b } \\
\text { Perforation I, } \\
\text { II, III, IV or V }\end{array}$ & $\begin{array}{l}\text { Length less than } 1 / 3 \text { of } \\
\text { diameter, either straight } \\
\text { or slightly curved sides. } \\
\text { Piercing types may vary. }\end{array}$ \\
\hline Chip & - & $\begin{array}{l}\text { No specific form, pierc- } \\
\text { ing through the shortest } \\
\text { section. Piercings very } \\
\text { small. }\end{array}$ \\
\hline Sub-spherical & $\begin{array}{l}\text { I.D1.a } \\
\text { Perforation II, } \\
\text { IV or V }\end{array}$ & $\begin{array}{l}\text { This type has no flatten- } \\
\text { ing at the end around } \\
\text { piercing. Piercing always } \\
\text { from both ends. }\end{array}$ \\
\hline $\begin{array}{l}\text { Long with round } \\
\text { section }\end{array}$ & $\begin{array}{l}\text { Similar to } \\
\text { I.D.1.b }\end{array}$ & $\begin{array}{l}\text { Length at least } 1.3 \text { times } \\
\text { diameter. }\end{array}$ \\
\hline $\begin{array}{l}\text { Long with lenticu- } \\
\text { lar section }\end{array}$ & $\begin{array}{l}\text { Similar to } \\
\text { I.D.1.b but } \\
\text { with IV.C.2.b } \\
\text { section }\end{array}$ & $\begin{array}{l}\text { Length more than } 5 \mathrm{~mm} \text {, } \\
\text { average more than } 8 \mathrm{~mm}\end{array}$ \\
\hline $\begin{array}{l}\text { Very long with } \\
\text { lenticular section }\end{array}$ & $\begin{array}{l}\text { Similar to } \\
\text { I.D.1.b but } \\
\text { with IV.C.2.b } \\
\text { section }\end{array}$ & Length more than $15 \mathrm{~mm}$ \\
\hline $\begin{array}{l}\text { Short with wide } \\
\text { lenticular section }\end{array}$ & $\begin{array}{l}\text { I.C.1.b but } \\
\text { with IV.C.2.b }\end{array}$ & $\begin{array}{l}\text { This type has flattened } \\
\text { ends around the piercing. } \\
\text { Wide size variation but } \\
\text { maximum width at least } \\
2 / 3 \text { of length. }\end{array}$ \\
\hline $\begin{array}{l}\text { Bell-shape with } \\
\text { wide lenticular sec- } \\
\text { tion }\end{array}$ & $\begin{array}{l}\text { I. D.1.g, but } \\
\text { with group IV } \\
\text { lenticular pro- } \\
\text { file }\end{array}$ & $\begin{array}{l}\text { Some have small flat- } \\
\text { tened end areas. Propor- } \\
\text { tions variable. }\end{array}$ \\
\hline Double sphere & I.C.1.a & $\begin{array}{l}\text { Two spheres joined to- } \\
\text { gether. All examples are } \\
\text { man made. }\end{array}$ \\
\hline Elongated drop & I.D.1.g & $\begin{array}{l}\text { Length is at least twice } \\
\text { maximum diameter. }\end{array}$ \\
\hline
\end{tabular}

\section{Shell beads and pendants}

There is a substantial assemblage of shell beads and pendants (more than $30 \%$ of the total) of both marine and freshwater species. The shell beads fall into two groups, those used in their natural form and those where shell is used as a raw material for the production of shapes unrelated to natural form. The former consists predominantly of Dentalium sp. shells $(60 \%)$ in long and slice form (Table 4, Fig. 6: 1 and 6: 2) with a single example of a Collumbella sp. shell (Fig. 6: 3). Although both Dentalium sp. and Collumbella sp. are marine species it is not yet established whether all the Dentalia were obtained from the sea; the very robust build and surface condition of some

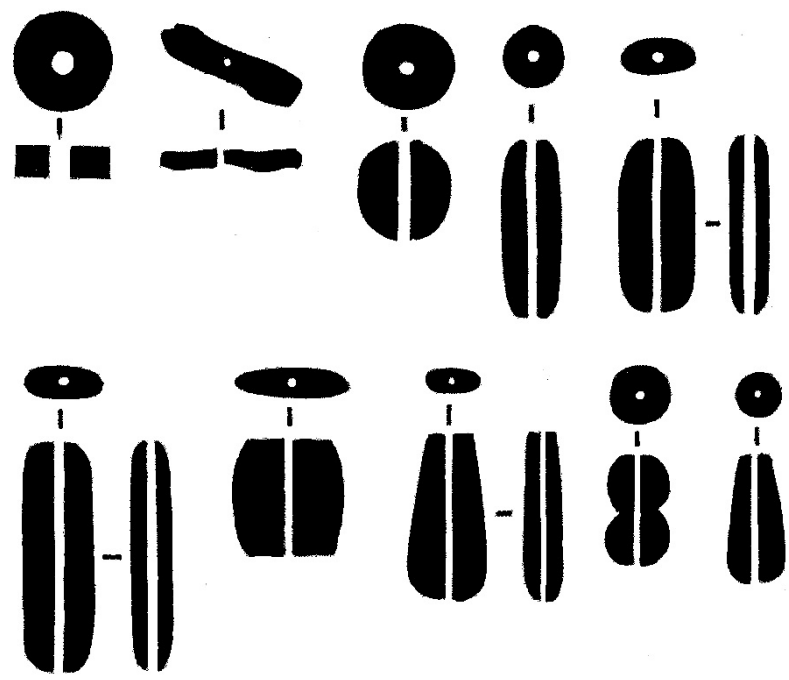

Fig. 5 : Schematized diagram of the blue bead types at Barcın Höyük.
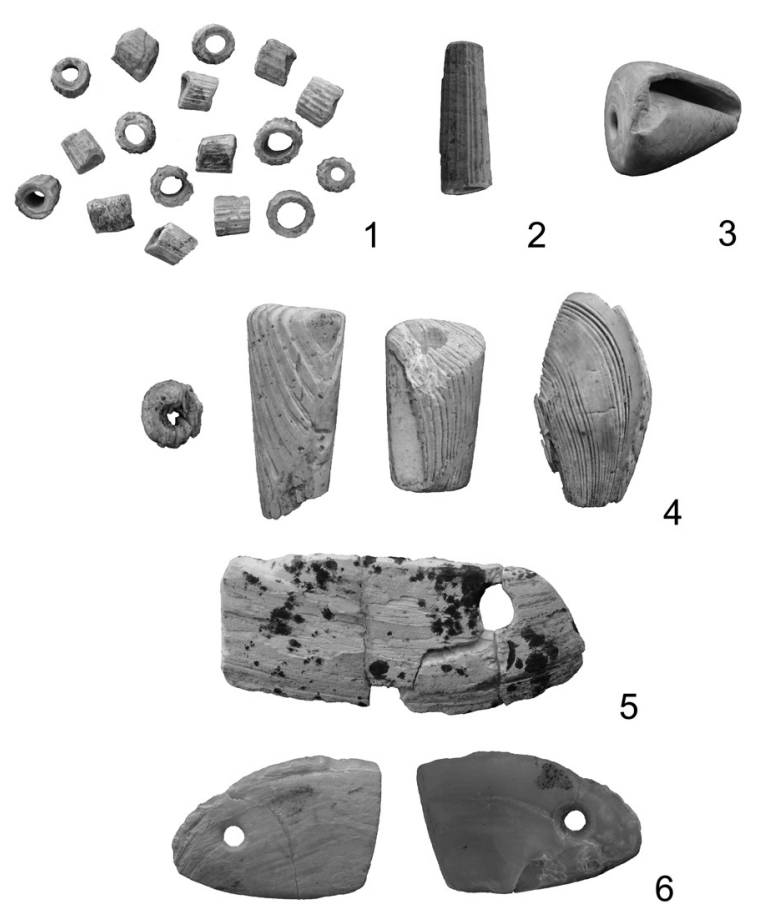

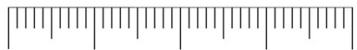

Fig. 6 : Examples of shell beads from Barcin Höyük. 1: Group of Dentalium sp. slices,

2: Long Dentalium sp., 3: Collumbella sp., 4: Group of large spondylus sp. beads, 5 and 6: flat ended pendants (unio sp.). 
Table 4 : Shell bead and pendant types found at Barcin Höyük (illustrated in Fig. 7).

\begin{tabular}{|c|c|c|}
\hline $\begin{array}{l}\text { Bead/pendant } \\
\text { form }\end{array}$ & $\begin{array}{c}\text { Beck } \\
\text { equivalent }\end{array}$ & Description \\
\hline Dentalium long & - & $\begin{array}{l}\text { Whole or trimmed den- } \\
\text { talium sp. pieces, length } \\
\text { greater than diameter. }\end{array}$ \\
\hline Dentalium slice & - & $\begin{array}{l}\text { Cut pieces of dentalium } \\
\text { sp., length less than di- } \\
\text { ameter. }\end{array}$ \\
\hline Large cone & $\begin{array}{l}\text { I.D.2.c } \\
\text { Perforation II, } \\
\text { IV or V }\end{array}$ & $\begin{array}{l}\text { Large flat area at one } \\
\text { end, straight sides. }\end{array}$ \\
\hline Large biconical & $\begin{array}{l}\text { I.D.2.e } \\
\text { Perforation II, } \\
\text { IV or V }\end{array}$ & $\begin{array}{l}\text { Symmetrical form, small } \\
\text { flattened areas around } \\
\text { piercings. }\end{array}$ \\
\hline Sphere & $\begin{array}{l}\text { I.C.1.a } \\
\text { Perforation I, } \\
\text { II, IV or V }\end{array}$ & $\begin{array}{l}\text { Symmetrical form, no } \\
\text { flattened end areas. }\end{array}$ \\
\hline $\begin{array}{l}\text { Square ended long } \\
\text { pendant }\end{array}$ & - & $\begin{array}{l}\text { Made from bivalve, sin- } \\
\text { gle piercing at rounded } \\
\text { end, }\end{array}$ \\
\hline Washer & $\begin{array}{l}\text { Similar to } \\
\text { A.2.b } \\
\text { Perforation I, } \\
\text { II, III, IV }\end{array}$ & $\begin{array}{l}\text { Length less than } 1 / 5 \text { of } \\
\text { diameter. Piercing types } \\
\text { may vary. }\end{array}$ \\
\hline $\begin{array}{l}\text { Collumbella with- } \\
\text { out whorl }\end{array}$ & - & $\begin{array}{l}\text { Very smooth, hole at } \\
\text { whorl end. }\end{array}$ \\
\hline Round pendant & - & $\begin{array}{l}\text { Manufactured from a bi- } \\
\text { valve. Variant form has } \\
\text { evenly spaced notches } \\
\text { around edges. }\end{array}$ \\
\hline Miscellaneous & - & $\begin{array}{l}\text { A variety of pendant } \\
\text { shapes made from bi- } \\
\text { valve pieces. }\end{array}$ \\
\hline
\end{tabular}

artefacts suggests that they may be fossil examples. The phenomenon of fossil collection has been documented at central Anatolian sites (Bar-Yosef Mayer et al. 2010) so would not be unexpected here.

Unio sp., or freshwater mussels, predominate the manufactured pendant assemblage (Gerritsen et al. 2013b: 67), with the recurrent production of a particular shape of flat-ended pendant (Table 4, Fig. 6: 5 and 6: 6). The fragile nature of these shells means that preservation is often poor; there are nine definite examples of this pendant type with another 40 broken examples of pierced bivalve shell which were probably originally of this pendant form, or similar shape. Manufacture relied partly on the natural shape of the lip of the bivalve to form a long curved side and made use of the groove on the inner surface of the lip area to aid piercing, which was always carried out from the inside in this pendant
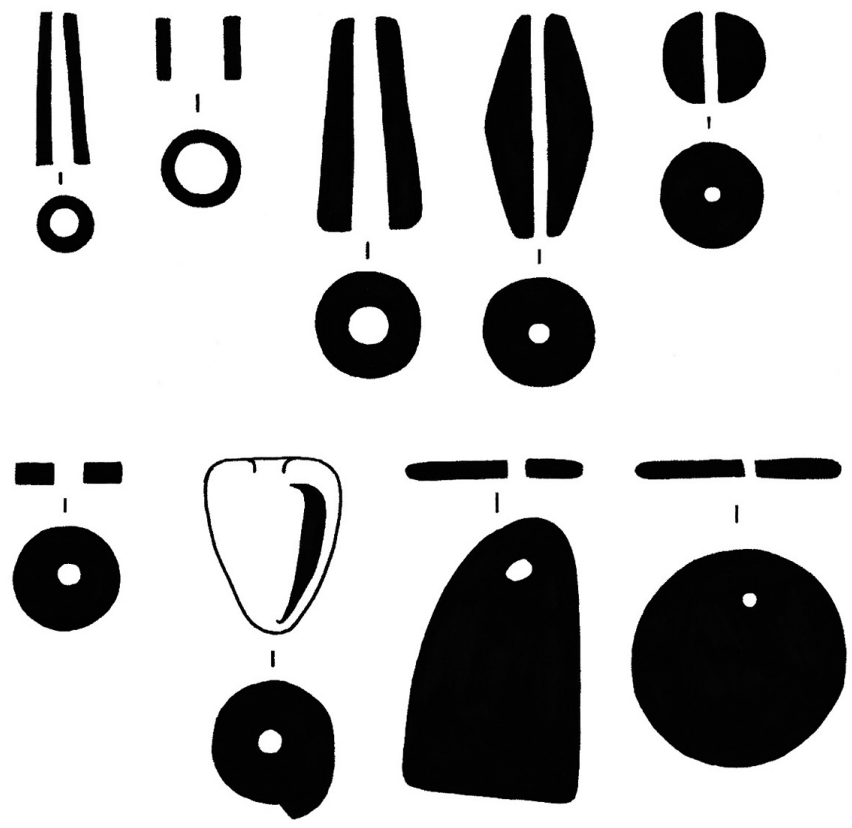

Fig. 7 : Schematized diagram of the shell bead and pendant types found at Barcm Höyük.

type. The secondary pendant type, much less common, was the circular form (Table 4, Fig. 7), again cut from a bivalve, with a single piercing and in some cases notched edges. In the case of these pendants care was taken to remove the original surfaces of the shell and make use of mother of pearl as the main visible surface.

There are a few beads of Spondylus sp. within the assemblage (Table 4, Fig. 6: 4 and 7), notably the larger examples were found in close proximity to each other. There are also a small number of manufactured disc beads produced from large (probably Spondylus sp.) shells that might be part of a pattern of use of white materials, which involved the use of Spondylus, Glycymeris and white marble in an apparently related production of both beads and bracelets. This activity extended across the Aegean, western Anatolia and the Balkans during the Neolithic and Chalcolithic (Ifantidis 2011; Dimitrijević and Tripković 2006; Gaydarska et al. 2004; Siklósi and Csengeri 2011; Bajnóczi et al. 2013; Chapman et al. 2012; Evans and Rasson 1984). The degree of standardization seen in the white marble disc beads is not replicated in the shell assemblage.

\section{Bone beads and pendants}

Bone and clay are the two least used bead materials at Barcin, each comprising less than $2 \%$ of the total assemblage. The bone assemblage is es- 
pecially limited in typology (Table 5, Fig. 8), probably as a result of the natural form of the small mammal long bones that were employed and perhaps also because the material was less valued than stone and shell for this purpose. The shape of the bone pendants (for example Fig. 8) is such that they may have been tools that were designed to be strung for convenience, or as part of their use, perhaps in net making or weaving. There is a single example of probable on-site manufacture of bone slice beads in the form of a bone with a series of deep and apparently unfinished grooves along its length.

Table 5 : Bone bead and pendant types at Barcın Höyük (illustrated in Fig. 8).

\begin{tabular}{|l|l|l|}
\hline $\begin{array}{c}\text { Bead/pendant } \\
\text { form }\end{array}$ & Beck equivalent & Description \\
\hline Slice & Type VII perforation & $\begin{array}{l}\text { Pieces of small } \\
\text { mammal bone, } \\
\text { cut using groove and } \\
\text { snap technique. }\end{array}$ \\
\hline Tube & Type VII perforation & $\begin{array}{l}\text { Similar to slice but } \\
\text { length greater than } \\
\text { diameter. }\end{array}$ \\
\hline $\begin{array}{l}\text { Pendants } \\
\text { (various) }\end{array}$ & - & $\begin{array}{l}\text { Varying forms of } \\
\text { pendant, pierced } \\
\text { once. }\end{array}$ \\
\hline
\end{tabular}
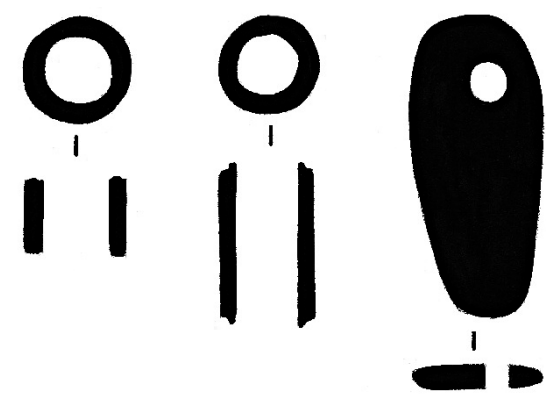

Fig. 8 : Schematized diagram of the bone bead and pendant types found at Barcın Höyük.

\section{Clay beads}

Clay beads are rare at Barcın Höyük despite the prolific manufacture and use of pottery at the site (Gerritsen et al. 2013b). Despite the malleability of the material the repertoire of forms is also remarkably conservative, consisting of just three types (Table 6, Fig. 9 and 10), all of which can also be found in other materials. The preliminary conclusion from this very limited usage of clay must be that this material was not as highly valued in the making of beads as stone and shell.
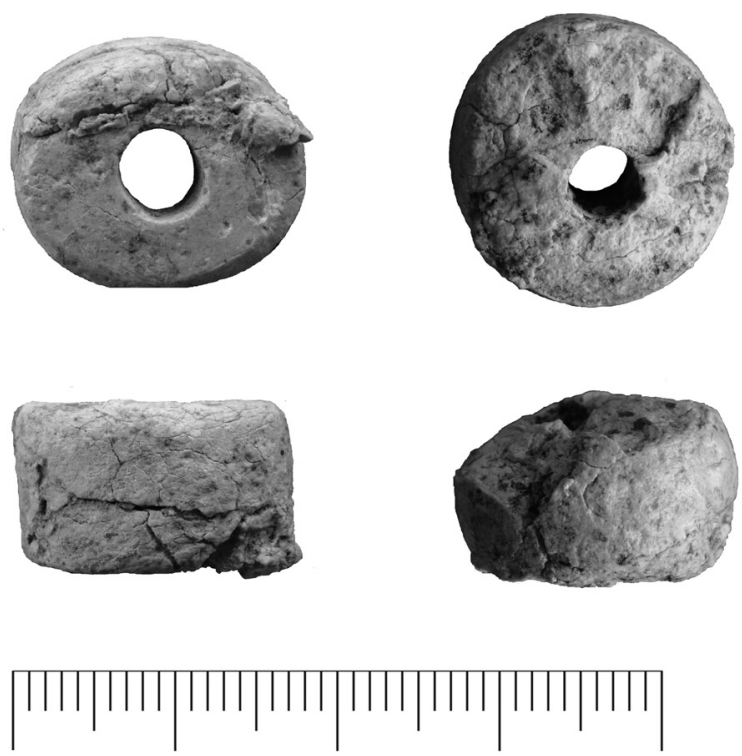

Fig. 9 : Large disc clay beads from Barcın Höyük.

Table 6 : Clay bead types found at Barcın Höyük (illustrated in Fig. 10).

\begin{tabular}{|l|l|l|}
\hline $\begin{array}{c}\text { Bead/pendant } \\
\text { form }\end{array}$ & Beck equivalent & \multicolumn{1}{|c|}{ Description } \\
\hline Disc & A.1.b, A.2.b & $\begin{array}{l}\text { Length less than 1/3 } \\
\text { of diameter, either } \\
\text { straight or slightly } \\
\text { curved sides }\end{array}$ \\
\hline Large disc & A.2.b, B.2.b & $\begin{array}{l}\text { Diameter is greater } \\
\text { than 10mm, propor- } \\
\text { tions vary from } 1 / 3 \text { to } \\
\text { 9/10 of diameter }\end{array}$ \\
\hline Globular & $\begin{array}{l}\text { Similar to I.C.1.b } \\
\text { Perforation II, IV } \\
\text { or V }\end{array}$ & $\begin{array}{l}\text { Flattened at ends } \\
\text { around piercing, } \\
\text { sides more curved } \\
\text { than Beck's example. } \\
\text { Piercing always from } \\
\text { both ends. }\end{array}$ \\
\hline
\end{tabular}
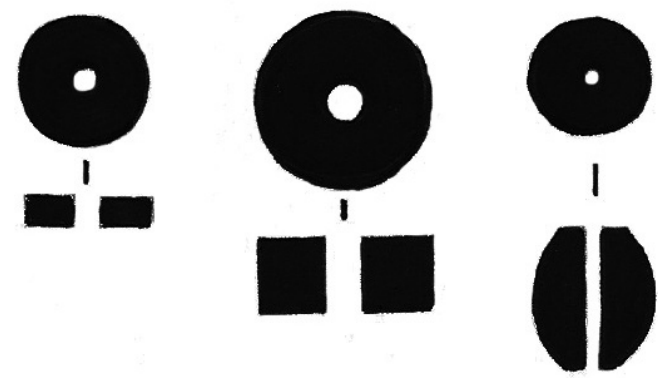

Fig. 10: Schematized diagram of the clay bead types found at Barcın Höyük. 


\section{DISCUSSION}

The range of bead types found at Barcin is remarkably diverse. Stone and shell are the dominant materials. A core of basic types, some of which were produced from multiple materials, can be identified thanks to relatively consistent production practices and little expedient or casual production. Likewise, size range, both in bead and piercing sizes shows a degree of standardization indicative of an idea of the desired appearance of each bead type in the minds of those manufacturing them. The beads have been divided by material for the purpose of discussion here and this reflects the relatively low level of overlap between the typologies of different materials. The disc bead is the most common, although it is far more dominant in stone than in other materials.

The striking difference between the main stone bead assemblage and that made of blue coloured materials is the distinction in both forms and manufacturing technology. The average length of blue beads is twice that of stone beads in general, and the average piercing diameter is also much smaller (blue beads average $1.36 \mathrm{~mm}$, general stone beads average $2.55 \mathrm{~mm}$ ). The only formal overlap is in disc and sub-spherical forms, it is provisionally hypothesized that the Barcin blue bead forms originate outside this site.

The proximity of Barcin to the Balkans is clearly seen in the use of shell at the site, which shows greater affinity to western practices than to the traditions of central and southeastern Anatolia. The use of Spondylus sp. is indicative of participation in bead and bracelet manufacture and use practices that were widespread across the Balkans and Aegean. Some affinities are seen with the long-lived traditions of bead procurement that are common to the whole of Anatolia and the Near East (Bar-Yosef Mayer 1997; 2008; Bar-Yosef Mayer et al. 2010; Reese 1991; Baysal 2009; 2013b), such as the use of Dentalium both in long (unaltered) and slice form.
Bone and clay both played a relatively minor role at the site, despite the intensive use of clay firing technology in pottery production (Gerritsen et al. 2013b). Both these materials also show very little formal variety, which may relate to production conventions rather than any limitations of the materials. This marries well with findings from other sites, which often indicate that these materials were less valued than stone and shell (Baysal 2013a).

These preliminary findings already indicate that different values were attributed to different bead forms and materials at Barcın Höyük. For example, the preference for the manufacture of certain forms in certain materials, such as white marble discs and orange globular forms. They also show that in many respects the site participated in wider material culture practices of the Neolithic. The use of stone disc beads being one of the most extensive traditions (Baysal 2009; 2013a). There are a variety of technological and contextual questions surrounding the Barcin assemblage, which will be addressed in the future. Insights into the technology of this bead assemblage will be provided once ongoing work on aspects of the blue bead assemblage, both natural and artificial, are completed (Baysal et al., in preparation).

Bar-Yosef Mayer's work on the analysis and classification of beads in the Levant $(2013 ; 2008$; Bar-Yosef Mayer and Porat 2008) is beginning make up for the deficit of work on the artefacts in previous decades, I hope that the increasing publication of prehistoric bead assemblages from Anatolia will begin to make up for the similar shortfall in this region. This artefact type deserves its place alongside the more widely considered artefact categories of the Neolithic period. There is potential to unlock indications of both the values of Neolithic populations and the way in which they presented themselves to, and interacted with, others.

E.B.

\section{BIBLIOGRAPHY}

Bajnóczi, B., Schöll-Barna, G., Kalicz, N., Siklósi, Z., Hourmouziadis, G., Ifantidis, F., Kyparissi-Apostolika, N., Pappa, M., Veropoulidou, R. and Ziota, C., 2013: "Tracing the source of Late Neolithic Spondylus shell ornaments by stable isotope geochemistry and cathodoluminescence microscopy", Journal of Archaeological Science 40: 874-882.

Bar-Yosef Mayer, D., 1997: "Neolithic shell bead production in Sinai", Journal of Archaeological Science 24: 97-111.
- 2008: "Dentalium shells used by hunter-gatherers and pastoralists in the Levant", Archaeofauna 17: 103110.

- 2013: "Towards a typology of stone beads in the Neolithic Levant", Journal of Field Archaeology 38.2: 129-142.

Bar-Yosef Mayer, D., Gümüş, B. and İslamoğlu, Y., 2010: "Fossil hunting in the Neolithic: Shells from the Taurus Mountains at Çatalhöyük, Turkey", Geoarchaeology 25.3: 375-392. 
Bar-Yosef Mayer, D., Porat, N., 2008: “Green stone beads at the dawn of agriculture", Proceedings of the $\mathrm{Na}$ tional Academy of Sciences 105.25: 8548-8551.

Baysal, E., 2009: The question, nature and significance of Neolithic craft specialization in Anatolia (Unpubl. PhD Diss.; University of Liverpool).

-2013a: "A tale of two assemblages: early Neolithic manufacture and use of beads in the Konya Plain", Anatolian Studies 63: 1-15.

- 2013b: "Epipalaeolithic marine shell beads at P1narbaşı: central Anatolia in a wider context", Anatolica 39: 261-276.

- Forthcoming a: "Identity, ornamentation and early specialization: beads from Pınarbaşı”, in Baird, D. (ed.), Pınarbaşı excavation final publication.

- Forthcoming b: "The social life of beads: manufacture and use of beads at Boncuklu Höyük", in Baird, D. (ed.), Boncuklu excavation interim publication.

Baysal, E., Gerritsen, F., Özbal, R. and Özbal, H., in preparation: "The evil eye in Neolithic Turkey. Scientific analysis of the manufacture of blue beads in the Neolithic".

Beck, H., 1928: "Classification and nomenclature of beads and pendants", Archaeologia 77: 1-76.

Caneva, I., 2007: "Mersin-Yumuktepe: son veriler 1şı̆̆ında MÖ yedinci binyıla yeni bir bakış", in Özdoğan, M. and Başgelen, N. (eds.), The Neolithic in Turkey, Istanbul: 203-216.

Cauvin, J., Aurenche, O., Cauvin, M.-C. and BalkanAtl1, N., 2007: "The pre-pottery site of Cafer Höyük", in Özdoğan, M. and Başgelen, N. (eds.), Neolithic in Turkey, Istanbul: 87-104.

Chapman, J., Gaydarska, B. and Balen, J., 2012: "Spondylus ornaments in the mortuary zone at Neolithic Vukovar on the middle Danube", VAMZ 3. S. 45: 191-210.

Dimitrijević, V. and Tripković, B., 2006: "Spondylus and Glycymeris bracelets: trade reflections at Neolithic Vinča-Belo Brdo", Documenta Praehistorica 33: $237-$ 252.

Erim-Özdoğan, A., 2011: “Çayönü”, in Özdoğan, M., Başgelen, N. and Kuniholm, P. (eds.), The Neolithic in Turkey Volume 1, Istanbul: 185-269.

Esin, U. and Harmankaya, S., 2007: “Aş1klı Höyük”, in Özdoğan, M. and Başgelen N. (eds.), The Neolithic in Turkey, Istanbul: 255-272.

Evans, R. and Rasson, J., 1984: "Ex Balkanis lux? Recent developments in Neolithic and Chalcolithic research in southeast Europe", American Antiquity 49.4: 713-741.

Gaydarska, B., Chapman, J. C., Angelova, I., Gurova, M. and Yanev, S., 2004: "Breaking, making and trading: the Omurtag Eneolithic Spondylus hoard", Archaeologia Bulgarica VIII (2): 11-33.

Gerritsen, F., Özbal, R. and Thissen, L., 2013a: "Barcın Höyük: the beginnings of farming in the Marmara region", in Özdoğan, M., Başgelen, N. and Kuniholm, P. (eds.), The Neolithic in Turkey, Vol. 5, Istanbul: 93-112.

- 2013b: "The earliest Neolithic levels at Barcin Höyük, northwestern Turkey", Anatolica 39: 53-92.
Hamilton, N., 2005: "The Beads", in Hodder, I. (ed.), Changing materialities at Çatalhöyük reports from the 1995-1999 seasons, Cambridge and Ankara: 325-332.

Ifantidis, F., 2011: "Cosmos in fragments: Spondylus and Glycymeris adornments at Neolithic Dispilio, Greece", in Ifantidis, F. and Nikolaidou, M., Spondylus in Prehistory: New data and approaches. Contributions to the archaeology of shell technologies. Oxford. Archaeopress BAR International Series 2216: 123-137.

Karul, N., 2007: “Aktopraklık: Kuzeybatı Anadolu'da gelişkin bir köy”, in Özdoğan, M. and Başgelen, N. (eds.), The Neolithic in Turkey, Istanbul: 387-392.

Özbal, R., Özbal, H., Gerritsen, F., Türkekul Bıyık, A. and Doğan, T., forthcoming: "New Observations for the Late Chalcolithic Settlement at Barcin Höyük", in Maner, Ç., Gilbert, A. and Horowitz, M. (eds.), From the silver mountain to the plains of the Amuq: Festschrift presented to $K$. Aslihan Yener for her 40 years of fieldwork archaeology in the Eastern Mediterranean. Leiden. Brill.

Öztan, A., 2007: “Köşk Höyük: Niğde-Bor Ovası'nda bir Neolitik yerleşim”, in Özdoğan, M. and Başgelen, N. (eds.), The Neolithic in Turkey, Istanbul: 223-236.

- 2010: "Archaeological investigations at Köşk Höyük, Niğde", in d'Alfonso, L., Balza, M. and Mora, C., Geo-archaeological activities in southern Cappadocia, Turkey, Pavia: 83-96.

Reese, D., 1991: "Marine shells in the Levant: Upper Palaeolithic, Epipalaeolithic and Neolithic", in Bar-Yosef, O. and Valla, F. (eds.), The Natufian Culture in the Levant, Michigan: 613-628.

Reiche, I., Vignaud, C. and Menu, M., 2000: "Heat induced transformation of fossil mastodon ivory into turquoise 'odontolite'. Structural and elemental characterization”, Solid State Sciences 2: 625-636.

Siklósi, Z. and Csengeri, P., 2011: "Reconsideration of Spondylus usage in the middle and Late Neolithic of the Carpathian Basin", in Ifantidis, F. and Nikolaidou, M., Spondylus in Prehistory: New data and approaches. Contributions to the archaeology of shell technologies. Oxford. Archaeopress BAR International Series 2216: 48-62.

Taniguchi, Y., Hirao, Y., Shimadzu, Y. and Tsuneki, A., 2002: "The first fake? Imitation turquoise beads recovered from a Syrian Neolithic site, Tell el-Kerkh", Studies in conservation 47.3: 175-183.

Wright, K. and Bains, R., 2007: "Stone bead technology at Çatalhöyük", Çatalhöyük 2007 Archive Report. http://www.ctalhoyuk.com/archive reports/2007/

Wright, K., Critchley, P. and Garrard, A., 2008: "Stone bead technologies and early craft specialization: insights from two Neolithic sites in eastern Jordan", Levant 40.2: 131-165.

Wright, K. and Garrard, A.N., 2003: "Social identities and the expansion of stone beadmaking in Neolithic western Asia: new evidence from Jordan", Antiquity 77: 267-284. 


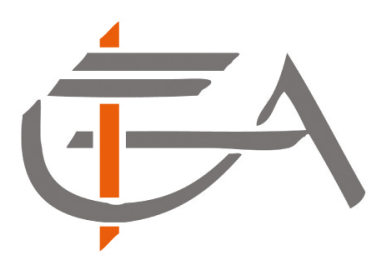

Institut Français

d'Etudes Anatoliennes

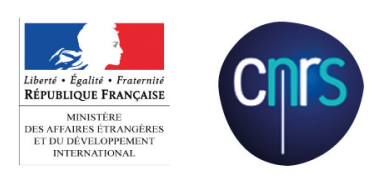

Peinture rupestre préhistorique, Sağlık Köy, près d'Alabanda, Turquie (cliché Suat Ateşlier). 